\title{
Determinants and Sustainability of International Reserves Accumulation in Nigeria
}

\author{
Mohammed Isa Shuaibu* \\ Taofik Ibrahim Mohammed ${ }^{*}$
}

\begin{abstract}
This paper examines the determinants and sustainability of international reserves accumulation in Nigeria. An assessment of the short- and long-run relationship between international reserves and its driving factors between 1970 and 2010 is carried out with a view of determining its sustainability, given the need to save against future exigencies. It makes use of error correction mechanism and the bounds testing approach to co integration within an autoregressive distributed lag framework proposed by Pesaran et al. (2001). The empirical estimates reveal that variability of export earnings, and the one period lagged value of international reserves positively affect reserve holding in Nigeria while oil price negatively affect it in the long-run. The economic (GDP per capita) and environmental ( $\mathrm{CO}_{2}$ emission) measures of sustainable development also affect international reserves accumulation in the long-run. The striking result from this study is that oil price negatively affects reserve holding in the long-run but is positive in the short-run. The findings suggest the need to diversify Nigeria's sources of external reserves accumulation towards more environmentally and economically sustainable activities such that the negative effects of volatile oil export earnings as well as crude oil extraction are minimized.
\end{abstract}

Keywords: International reserves, Nigeria, Bounds test, Sustainable, Oil price, Export

JEL Classification: F31, Q56

\section{Introduction}

The need for accumulation of international reserves by monetary authorities is imperative, not only in view of uncertain global economic environment but also given the need to pursue development and growth in a sustainable manner. Domestic market distortions induced by these conditions require government intervention via

\footnotetext{
* Mohammed Isa Shuaibu and Taofik Ibrahim Mohammed are at Department of Economics, University of Ibadan, Ibadan, Nigeria
} 
reserves depletion. Thus, vulnerability and exposure of a developing country like Nigeria to external shocks via the trade and finance channels, makes adequate reserves important towards achieving governments' macroeconomic objectives specifically and sustainable growth and development efforts in general. The need for increased efforts toward ensuring adequate and international reserves buffer without hampering the requisite economic, social and environmental interplay for sustained inclusive growth and development cannot be downplayed.

Over-reliance on crude oil for over 90 percent of Nigeria's foreign exchange earnings makes its external account susceptible to international crude oil price fluctuations. This has been further exacerbated by contemporaneous foreign exchange market intervention and high import bills that have contributed to the level of fluctuations in reserve holdings. Nigeria's reserve stock has risen from a mere US\$0.15bn in 1970 to over US\$51 billion in 2007. However, in more recent times, Nigeria's reserve stock declined from about US\$53bn in 2008 to about US\$42bn, US\$32bn and US\$33 in 2009, 2010 and 2011 respectively. This trend, relative to the high accumulation experienced in the first half of the last decade as earlier stated, may be due to high import financing, foreign exchange market intervention and unfavorable global crude oil market conditions. This has resulted in higher pressure on fiscal and monetary policies, thus hindering the attainment of desired macroeconomic objectives of government.

Further, financial crisis occasioned by global economic slowdowns and resultant boom-bust cycles that spill over to low-, middle-, and high-income economies have undermined policy implementation. Such a scenario makes the Nigerian economy more susceptible to the vagaries of global trade and financial condition given its weak productive capacity, oil dependence, weak governance and uncertain reserve accumulation. This implies that weak sustainability conditions are hardly met, given the persistent depletion of capital resources and the sub-optimal capacity to generate capital stock.

Further, fundamental elements of sustainability (fairness and equity) have been hampered by financial globalization and its inherent weaknesses. Inadequate buffers to stabilize the economy in the event of sudden stops and reversals of oil revenue earnings and capital inflows in addition to the consequent environmental damages induced by crude oil production implies that reserve management strategies need to integrate environmental and social concerns. In the absence of sustained reserve accumulation, the consequence on aggregate economic activities is enormous as real sector productivity bubbles burst, leading to a slowdown in economic activities.

The driving factors of international reserve holdings have been modeled within different frameworks such as the buffer stock/precautionary postulation, monetary approach, mercantile perspective, insurance value approach amongst others. Yet most of these studies have paid less attention to the sustainable management of 
reserves and its driving factors which in turn enhances its stability. Recent developments in the literature on international reserves have raised important questions on (i) how do you ensure a balanced interplay between international reserves and sustainable development? And; (ii) is there a causal link between international reserves and oil price variations? Answers to these questions using a dynamic modelling approach and within a country-specific framework provide insight on the determinants and sustainability of international reserves accumulation in Nigeria. It also provides ample opportunity to position the economy towards sustainable saving and fiscal expansion given the huge savings and investment gap that characterises the economy. Thus, this paper will seek to empirically analyze the factors that drive foreign reserves accumulation holding in Nigeria in a bid to proffer sustainable and efficient plans that can spur inclusive growth in a socially and environmentally optimal manner. The need for an empirical examination of external reserves in Nigerias' short and long run are derived from two interrelated factors. First is the critical importance of reserve determinants in predicting reserve accumulation in particular and its trend in general, particularly towards future development planning. Second is the role of these determinants in the design of effective and holistic macroeconomic policies to ensure sustainable stability and confidence in the economy.

There is a vast literature on the subject matter [See Bankole et al. (2011); Abdul-Lateef and Waheed (2010); Usman, (2005); Obaseki (2007); Ball and Reyes (2006); Cheung and Ito (2007); Elhiriaka and Ndikumana (2007); Parent and Gosselin (2005); Aizenman and Lee (2005); Sehgal and Chandan (2008) etc]. However, some of these studies carried out for Nigeria are limited as they have been based on descriptive analysis, but the studies by Bankole et al. (2012) and Abdulateef and Waheed (2010) are exceptions as they have used the Engle and Granger (1987) co-integration test and the Johansen (1988) and Johansen and Juselius (1990) co-integration test. These approaches may not be appropriate, especially when a small sample size is considered (see, Narayan and Smyth 2005). In this regard, we propose to use the bound testing approach within an autoregressive distributed lag framework proposed by Pesaran et al. (2001) to estimate a demand for reserves equation. Furthermore, it is evident that none of the studies have taken into consideration, the dependence of Nigeria's export earnings on international crude oil prices that have been very unstable overtime. Hence, one would expect global oil price to have a significant influence on Nigeria's reserve holdings. The vulnerability of Nigeria's macroeconomic fundamentals to the vagaries of international crude oil market conditions has been reflected in the pace of international reserves. Although the study by Shuaibu and Mohammed (2013) examined the determinants of external reserves using the ARDL bounds test approach, they failed to account for the issue of sustainability which plays a fundamental role towards Nigeria's reserve accumulation. 


\section{Facts about International Reserves in Nigeria}

International reserves management in Nigeria began with the emergence of the First National Development Plan (1962-68) and the 1967-70 civil war, which was characterized by massive fiscal expenditures and the resultant persistent depletion of external reserves. Crude oil has since its discovery in commercial quantities driven the revenue-expenditure profile of the country. Nigeria is a monoculture economy characterized by over-reliance on crude oil earnings and as a major oil producer, international crude oil price volatilities make the economy vulnerable. For instance, the prolonged oil glut of the 1980s led to current account deficits and subsequent economic turbulence experienced while the burgeoning of external reserve occasioned by the increase in international crude oil prices has led to a steady decline in the balance of payment deficits in the last decade. Two phases alternately marked by reserve accumulation and depletion depicts the Nigerian situation and have occurred contemporaneously with the major oil price shocks and domestic imbalances over the period of 1970-2007. During 1970 - 71, 1973 - 75, 1979 - 80, the net performance of the external sector resulted in the accumulation of foreign reserves; on the other hand, during the periods of 1972, $1976-78$, and $1981-82$, Nigeria experienced severe balance of payments crisis culminating in a rapid depletion of external reserve.

Foreign reserve assumed a sharp rise in the 1973-1974 periods due to the first oil price shock influenced by the oil embargo in October 1973. The 1980s and particular-

Figure 1. Trend of Foreign Reserve, Output and Export Earning in Nigeria

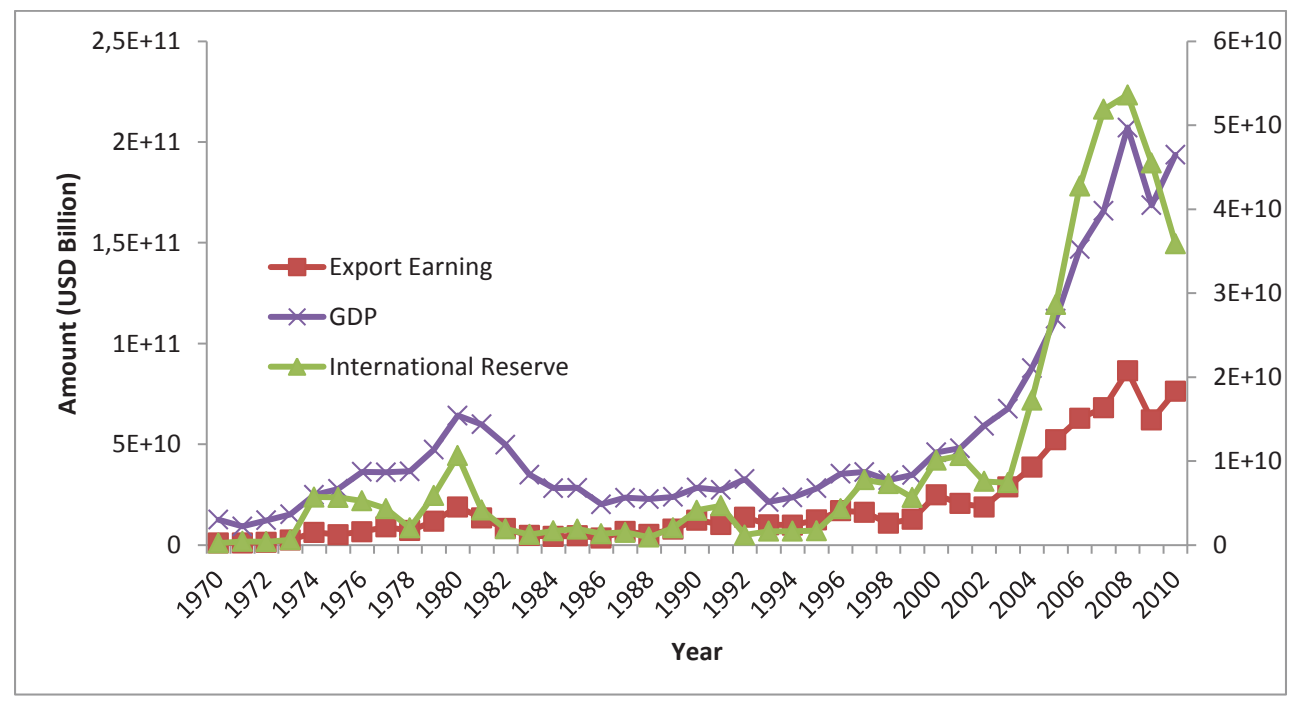


ly 1983 represent the period of the oil glut which reduced oil export earnings and thus reserves. The period was also characterized by external indebtedness. For instance, Nigeria's oil revenue inflows fell from over US\$25 billion in 1980 to US $\$ 6.4$ billion in 1986. Increase in oil exports in the 1990s raised external reserve holdings to levels higher than in the 1970s and 1980s. The trend of external reserve in the 1990s was relatively stable except for 1992, which saw a sharp decline by about 74 percent to a meager USD 0.7 billion and there from maintained an upward trend before rising sharply to USD10.42 billion in 2001. Since 1999, external reserve witnessed a relatively stable and gradual pile up attributable to higher export earnings, tight fiscal stance of government and the reduced debt service burden induced by the debt relief.

The country's crude oil output per day rose from one million barrels in 2008 to about 2.6million barrels per day. This remarkable improvement which surpasses its OPEC quota of about 2 million barrels per day is due to a relatively stable Niger-Delta region occasioned by the government's amnesty programme. Also, persistent and unprecedented rise of international crude oil prices during the last decade in addition to robust domestic indicators like downward trending and/or single digit inflation, stable exchange rate, low fiscal deficits and debt relief, sustained growth in domestic output have led to phenomenal growth in external reserve position from a meager US $\$ 0.15$ billion in 1970 (equivalent of 1.7 months of import cover) to US $\$ 4.99$ billion in may 1999. By 2002, the foreign reserve stood at US\$7.7 billion. The external reserve level rose to US\$43.5 billion in 2006 (equivalent to 28.4 months of import cover). The gross reserve as at end of December 2007 stood at over US\$51billion and increased to over US\$63 billion as at August 2008.

Figure 2. Reserve Growth Rate, Interest Rate, Openness and Oil Price Movement

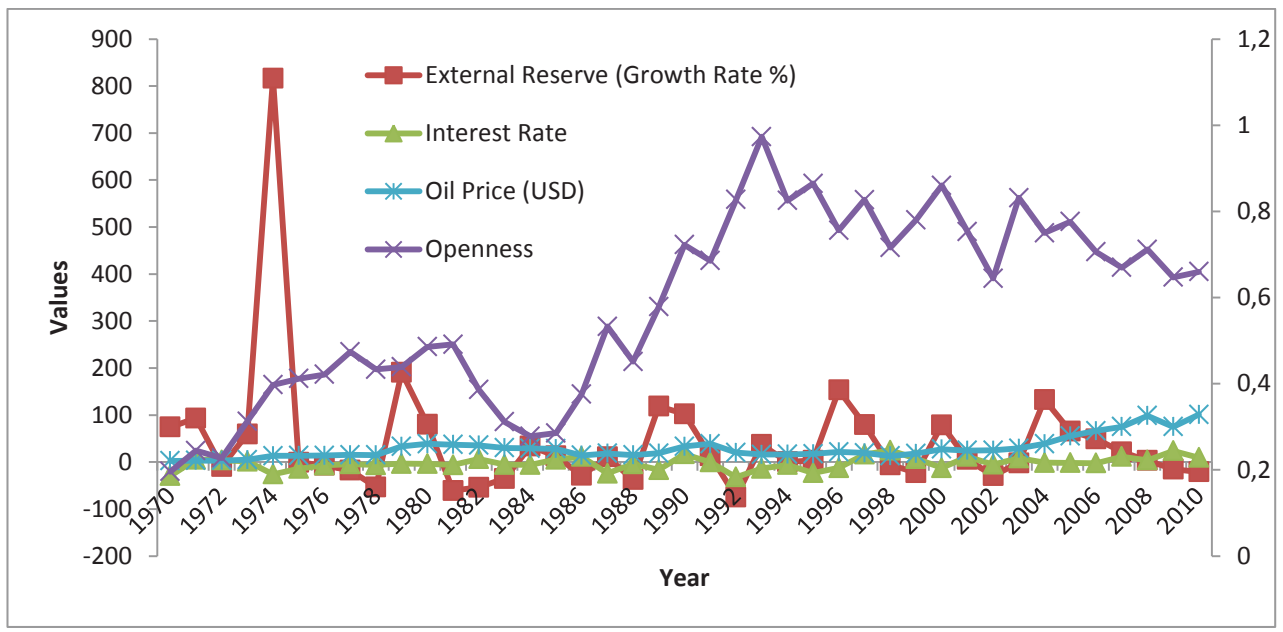




\section{A Skeletal View of the Literature}

\section{Review of Theoretical Issues}

In the economic debate, sustainable development is most often described as the need to maintain a permanent income for humankind, generated from non-declining and/ or non-declining (my italics) capital stocks (Spangenberg, 2005). Yet, the role of interand intra-generational equity, economic, social and environmental sustainability have been ignored by policy makers as they have focused more on massive fiscal expansions to meet immediate demands, often times induced by political pressures as the basis of investment decisions. Inadequate emphasis on financial sustainability, particularly reserve accumulation is a source of tends to undermine economic sustainability and this widens domestic income and foreign exchange gaps. In the light of global financial market uncertainties, domestic policies geared towards promoting sustainable growth and development accompanied by "trickle-down" effects, should consider wealth preservation in form of reserve accumulation and sovereign wealth fund (SWF) in a bid to minimise the likelihood of crisis and ensure economic stability. While the application and integration of sustainable development and issues of sustainability to mainstream economic theories is still at its infancy, nevertheless, such pursuits have been made and the literature is expanding (See Pearce and Atkinson, 1993; Spandenberg, 2002; Spandenberg et al. 2002; Spandenberg, 2005; Bockerman et al., 2005).

An economically sustainable system must be able to produce goods and services on a continuing basis, to maintain manageable levels of government and external debt, and to avoid extreme sectorial imbalances which damage agricultural or industrial production. In the real world, we can rarely avoid trade-offs. As noted by Norgaard (1994), we can maximize only one objective at a time: 'it is impossible to define sustainable development in an operational manner in the detail and with the level of control presumed in the logic of modernity. The strongly normative nature of the sustainable development concept makes it difficult to pin down analytically. However, its role towards the theoretical developments of economic postulations cannot be downplayed as the integration of sustainable development and allied concepts in economic models improves their explanatory power, particularly with respect to sustainability of economic policies.

Keynesians argued that three motives gives rise to the demand for cash balances (transaction, precautionary and speculative reasons).The same argument follows for countries however, as noted by Heller (1966), the transaction motive, while being important for the individual economic unit, plays no role in the decision of monetary authorities as to what their optimal portfolio composition should be. This implies that Central Banks will in general not be involved in speculative activity and therefore, need not hold any speculative balances. In contrast to the Keynesian view, classical monetary theory in the Cambridge cash balance approach had argued that individuals 
will need money for transaction purpose only. Modern monetarists on the other hand argued that demand for money is no longer a function solely of interest and income, but that the rate of return on a much wider spectrum of physical and financial assets which they argued will influence an individual's demand for money. The basic analytical approach of most studies on international reserves has been the argument of the equivalence of the transaction, precautionary and speculative motive for holding cash balances by individuals and countries reserve holding and accumulation. However, the transaction motive while being important for an individual economic unit plays no role in the decision of monetary authorities as to what their optimal portfolio composition should be. The precautionary motive is of dominating influence in the decision of monetary authorities to hold certain stocks of liquid assets (Heller, 1966).

Miller and Orr (1966), Heller (1966), Frenkel and Jovanovic (1981) amongst others pioneered the modelling of desired money holding in a stochastic inventory theoretic framework. An important extension of this model is the evolution of the precautionary reserve holding model which has guided empirical specification of several studies. For instance, Frenkel and Jovanovic (1981), Frenkel (1983), Edwards (1983), Lizondo and Mathieson (1987), Parent and Gosselin (2005) and Flood and Marion (2002) have used the buffer stock model. According to Aizenman (2005), the buffer stock model predicts that average reserves depend negatively on adjustment costs, the opportunity cost of reserves, and exchange rate flexibility; and positively on GDP and on reserve volatility, driven frequently by the underlying volatility of international trade. Again this highlights the restrictiveness of these theories to comparability and commensurability (at least in the monetarist perspective) and imposes limitations to the analytical capacity of linking sustainable development analysis to the theory. An alternative perspective relies on the monetary approach to balance of payment and relates changes in international reserves to changes in money demand (See Edward (1984) and Elbadawi (1990)). In a bid to ascertain the sources, effects and motivation for reserves in African countries, Elhiarika and Ndikumana (2007) rely on the monetary approach to balance of payment as the analytical basis of their work. While the precautionary approach links reserves accumulation directly to exposure to sudden stops, capital flight and volatility, the mercantilist approach views reserves accumulation as a residual of an industrial policy, a policy that may impose negative externalities on other trading partners (Aizenman and Lee, 2005). The thrust of the mercantilist motive is to save reserve in a bid to reduce or prevent appreciation, with the ultimate goal of increasing export-led growth.

Another postulation is that driven by the insurance value of reserves. Lee (2004) developed a quantitative framework for modelling reserves and proposes the insurance motive for holding reserves. This insurance value of reserves is quantified as the market price of an equivalent option that provides the same insurance coverage as reserves. This framework creates an avenue for analysing optimal reserve holding decision and can be invoked in calculating the cost of a regional insurance arrangement. 
The model views reserve holding as an act of self insurance. The insurance view fits well in the literature of the demand for reserves that has developed at par with the theory of demand for money.

A clear observation from the literature is the fact that the issue of sustainability has been ignored as early theories focused on short- to medium-term reserve accumulation without consideration for the critical role of sustaining accumulation over a long period of time. This is particularly true in the case of Nigeria and other resource dependent economies, where the role of oil revenue earnings cannot be downplayed even in the presence of alternative revenue sources. Again, the issue of sustainability has played a minor role in these debates. While there are ideas found in the literature regarding the environmental, social and sometimes also the institutional sustainability of the economic system, there is hardly any information available on the economic sustainability of the economy with particular reference to external reserve accumulation.

\section{Review of Methodological Issues}

The major methodological techniques used in estimating the determinants of reserve equations are Ordinary Least Square (OLS), two Stage Least Square (2SLS), panel data and time series analysis. Iyoha (1976) in addition to estimating a cross country equation using ordinary least squares, introduced a distributed lag model to capture past behaviour of the variables used in the study. Heller and Khan (1978) further investigates the question raised by Frenkel (1978), for which they estimate ARIMA models for reserves of the six country groupings with quarterly data over the period 1964-76. Following the model specification of Frenkel and Jovanovic (1981), Ben-Bassat and Gottlieb (1992) tried to estimate the opportunity cost with respect to demand for reserves but find that the OLS estimates were inefficient with biased t-values. They thus opted for autoregressive process, moving average and a synchronisation of both techniques and found that the first order moving average produced the best result as it significantly improved parameter estimates.

Burke and Lane (2001) used OLS with heteroscedastic consistent standard errors to study the determinants of cross-country variations in the level of international reserves over $1981-1995$ and as predicted shows that trade openness is the pivot variable in the model estimated. They also provide evidence that shows that volatility, capital controls, exchange rate regime or oil dependence independently influences level of reserves. Aizenman, Lee and Rhee (2004) relied on reduced form regressions and structural models to assess the responsiveness of international reserves to current account and net equity, debt and other investment inflows in the balance of payment, short term external debt. Using Two Stage Least Square (2SLS), Ball and Reyes (2006) tried to regain the statistical relevance of interest rate as a key determinant of reserve accumulation. After controlling for endogeneity, they found that the oppor- 
tunity cost of holding reserve plays a prominent role in ascertaining reserve holding. They also use dummy variables of exchange rate regimes to see its implications on reserve holding.

Cheung and Ito (2007) considered a scaled measure of reserves using three categories of determinants (macro, financial and institutional variables) and dummy variable, employ regression equations and try to ascertain the cross-sectional behaviour of three non-overlapping sample periods. Choi, Sharma and Stomqvist (2007) examined the link between capital flows, financial integration and the accumulation of international reserves by countries, given financial frictions and information problems. They estimate panel data models and take account of economy size, import share, exchange rate variability, exchange rate regimes, world interest rates, and fiscal conditions. Jo (2007) used co-integration and error correction models to estimate the magnitude and sources of international reserves accumulation and thus provide evidence to show that Korea albeit strong skewness for export competitiveness has stockpiled reserves.

Obstfeld, Shambaugh and Taylor, (2008) in their study, presented a simple heterogeneous-forecast model to illustrate the positive linkage between the size of the banking sector and a country's demand for international reserves in a bid to demonstrate how the banking sector can generate demand for foreign reserves if the central bank pursues some degree of exchange rate stability objective. They compare variables used in the traditional models (precautionary and mercantilist) with the financial stability model using a simple pooled OLS specification. Ford and Huang (1994) made use of error correction model to investigate the demand for international reserves in China while inculcating monetary disequilibrium into the model to capture disturbances from the domestic markets and found that reserve holdings in China have maintained a long-run relationship and a stable dynamic relationship with several determinants since the 1950s.

While several studies have tried to justify the need for holding external reserves, there has been a somewhat synchronised argument regarding the need to hold foreign reserves for precautionary reasons or to serve as buffer stock against unforeseen occurrences, to promote or drive export-led growth (mercantilist motive). It is apparent that the explanatory variables used in the models adapted in some of these studies to explain foreign reserve behaviour are somewhat similar but differ markedly in the area of proxies used for some of the variables. In addition, most of the studies examine reserves in a group of country sample and in some cases use narrower set of explanatory variables.

\section{Review of Empirical Issues}

Most empirical outcomes in economics-sustainable development literature have focused on capital being maintained independently and saved for future generations. 
However, international reserves have to be drawn down to for instance, intervene in the foreign exchange market and/or to meet import financing needs. In the international reserve literature, the issue of sustainability has not been given adequate attention and this may be due to the growing interest on the issue of reserve management. Empirical investigation of macroeconomic determinants of international reserves in Nigeria is scarce. However, recent efforts have been made for Nigeria by Bankole et al. (2012) and Abdul-Lateef and Waheed (2010). Specifically, Bankole et al. (2012) found that current account variability and past levels of external reserves drive reserve holding in the short run. In the long run, the former and the money supply are significant determinants. Abdul- Lateef and Waheed (2010) presented similar findings.

Heller (1966) tries to compress the different factors that influence reserves into a single index and finds, in a simplified analysis that propensity to import, opportunity cost, and stability of international accounts has a linkage with optimal level of international reserve holding. Specifically, an increase in the propensity to import and opportunity cost would decrease the level of optimal reserves while an increase in international account will increase international reserve holding. Courchene and Youssef (1967) attempted to ascertain the determinants of international reserves and provide evidence that money supply is more significant than imports in explaining external reserve holding. They also find interest rate to be significant in explaining reserve holding. Iyoha (1976) tried to find the determinants of international reserves by the monetary authorities of less developed countries. Using a cross country regression for 29 Less Developed Countries (LDCs) in 1970, he found that the opportunity cost variable is a vital determinant of reserve holding.

Economic sustainability requires that the different kinds of capital that make economic production possible must be maintained or augmented. These include manufactured capital, natural capital, human capital, and social capital. Some substitutability may be possible among these kinds of capital, but in broad terms they are complementary, so that the maintenance of all four is essential over the long term. A formal economic analysis then raises the question of whether sustainability has any validity as an economic concept. According to standard economic theory, efficient resource allocation should have the effect of maximizing utility from consumption. If we accept the use of time discounting as a method of comparing the economic values of consumption in different time periods, then sustainability appears to mean nothing more than efficient resource allocation - a concept already well established in economics.

Ben-Bassat and Gottlieb (1992) in an empirical study of the effect of opportunity cost on international reserve holding on Israel during the period $1968-1988$ found that if measured correctly, opportunity cost plays a pivot role in determining reserves. Dow (2001) estimated the demand for excess reserves in the United States and finds that excess reserves are negatively related to the Federal funds rate and 
positively related to transactions deposits. The study also finds that clearing needs significantly affect the demand for reserves with increases in excess reserves coming in response to lower required reserve balances and higher clearing volume.

Lane and Burke (2001) examined the cross-country variations in the level of international reserves using regression analysis over the period 1981 - 95 and found that trade openness is the most important of all the variables they considered. The authors also provided evidence that financial deepening is correlated with an increase in reserve ratio and add that, indebted developing economies tend to have small reserve ratios.

Flood and Marion (2002) estimated optimal reserve holdings for countries under various monetary regimes and found that in a world with high capital mobility, interest rates are weakly significant and thus not robust estimates in explaining reserve holdings. However, Ball and Reyes (2006) argued strongly against such findings (from Flood and Marion (2002)), and thus carry out a two stage least square analysis due to endogeneity of interest rates and international reserves under fixed exchange rate regimes to buttress the importance of interest rates. They found that interest rate was statistically significant in their specification. IMF (2003) utilised a large panel of emerging market economies during the period 1980-1986 and found that real GDP per capita, population level, ratio of import to GDP, and exchange rate volatility were statistically significant determinants of real reserves whilst measures of capital account vulnerability and opportunity cost were insignificant in explaining reserve holding.

Badinger (2004) attempted to estimate Austria's demand for international reserves over the period 1985:1-1997:4 and test for short-run effects of the disequilibrium on the national monetary market. He found that Austria's long-run reserve demand can be described as a stable function of imports, uncertainty and the opportunity cost of holding reserves with strong economies of scale. The speed of adjustment takes a value of 38 per cent. Aizenman, Lee and Rhee (2004) using the buffer stock model sought to reduce the incidence of costly output driven by short term reversal of capital flows. They show that the Asian crisis of 1997/1998 led to structural changes in hoarding reserves. Trade openness they found was significant before the crisis but insignificant after the crisis in explaining reserve behaviour.

Aizenman and Marion (2003) investigated the interpretation of relatively high demand for international reserves in the Far East (emerging Asia) and the relatively low demand by some other developing economies (e.g. Africa and Latin America). They found that reserve holding over the period 1980 - 1996 is a function of some key factors such as the size and volatility of international transactions, exchange rate arrangement, political corruption, and external borrowing. Their model specification shows that sovereign risk, costly tax collection to cover fiscal liabilities and loss aversion lead to relatively large build-up of reserves.

Cheung and Ito (2007) conducted an extensive empirical analysis of determinants of international reserves holding using data for over 100 economies during the peri- 
od 1975 - 2004. Using regression analysis and dummy variable models, they found that the relationship between external reserves and its determinants differ between developed and developing economies and is not stable overtime. Furthermore, their estimation results indicate that especially during the recent period, a developed economy tends to hold a lower level of international reserves than a developing country. Obstfeld, Shambaugh and Taylor (2008) tried to ascertain the empirical determinants of reserve growth in a broad panel of developing, emerging and advanced economies. Their analysis shows that there has been a statistically robust and economically significant correlation of reserve levels (reserves/GDP) with financial openness (a measure of cross-border capital mobility), financial development (proxied by M2/GDP), and exchange rate policy (using peg indicators). They also take account for some traditional variables and found that trade is statistically significant while foreign debt was statistically insignificant.

\section{Methodology}

\section{Theoretical Framework and Model Specification}

We rely on a specification in line with (Iyoha, 1973) where international reserve is a function of variability of export earnings (VEE) opportunity cost of holding reserves (OC), degree of openness of the economy (OPEN), and oil price (OP).We include GDP per capita (GPC), political stability index (PSI) and $\mathrm{CO}_{2}$ emission (COE) as economic, social and environmental measures of sustainable development respectively. This represented below as;

$$
R^{*}=\varphi(\text { vee, oc, open, op, gpc, coe, } p s i) ; \varphi_{1}, \varphi_{2}, \varphi_{3}, \varphi_{5}>0, \varphi_{4}, \varphi_{7}<0, \varphi_{6}<0 .
$$

Theoretically, the higher the magnitude of openness of an economy, the higher the optimal reserve holding as the increased openness implies greater exposure to external shocks. Thus, an economy open to global trade and financial flows and thus exposed to external disequilibria requires a higher buffer stock in its portfolio holdings. The higher the interest rate on foreign exchange holdings, the higher the optimal reserve level since a higher interest rate implies a lower opportunity cost of holding reserves. The higher the variability of export earnings, that is, the greater the instability of export receipts, the higher will be the optimum level of reserves. If there is much instability, the probability of a large deficit is high. The impact of oil price on reserve could be negative or positive depending on the direction of the shock. In terms of sustainability, the economic measure is expected to be a positively related to reserves while the environmental measure is expected to inhibit reserve accumulation. The social measure could be negative or positive. 


\section{Estimation Techniques}

The Auto-Regressive Distributed Lag (ARDL) bounds testing approach for testing the existence of a cointegrating relationship by Pesaran et al. (2001) is used. The bound testing approach has certain econometric advantages in comparison to other single cointegration procedures (such as Engle and Granger, 1987; Johansen and Juselius, 1990). Firstly, endogeneity problems and inability to test hypotheses on the estimated coefficients in the long-run associated with the Engle-Granger (1987) method are avoided. Secondly, the long and short-run parameters of the model in question are estimated simultaneously. Lastly, the econometric methodology is relieved of the burden of establishing the order of integration amongst the variables and of pre-testing for unit root.

The ARDL approach to testing for the existence of a long-run relationship between the variables in levels is applicable irrespective of whether the underlying regressors are purely $I(0)$, purely $I(1)$, or fractionally integrated. Finally, as argued in Narayan (2005), the small sample properties of the bounds testing approach are far superior to that of multivariate cointegration. The approach, therefore, modifies the Auto-Regressive Distributed Lag (ARDL) framework while overcoming the inadequacies associated with the presence of a mixture of $I(0)$ and $I(1)$ regressors in a Johansen-type framework.

From equation (1), the ARDL representation of international reserve equation is presented as follows:

$\Delta \ln r=\alpha_{0}+\alpha_{1} \ln r_{t-1}+\alpha_{2} \ln v e e_{t-1}+\alpha_{3} o c_{t-1}+\alpha_{4} \ln o p e n_{t-1}+\alpha_{5} \ln o p_{t-1}+\alpha_{6} \ln g p c_{t-1}+\alpha_{7} \ln c o e_{t-1}$

$+\alpha_{8} p s i_{t-1}+\sum_{i=1}^{j} \beta_{1 i} \Delta \ln r_{t-i}+\sum_{i=1}^{j} \beta_{2 i} \Delta \ln v e e_{t-i}+\sum_{i=1}^{j} \beta_{3 i} \Delta o c_{t-i}+\sum_{i=1}^{j} \beta_{4 i} \Delta \ln$ open $_{t-i}+\sum_{i=1}^{j} \beta_{5 i} \Delta \ln o p_{t-i}$

$+\sum_{i=1}^{j} \beta_{6 i} \Delta \ln g p c_{t-i}+\sum_{i=1}^{j} \beta_{7 i} \Delta \ln c o e_{t-i}+\sum_{i=1}^{j} \beta_{8 i} \Delta p s i_{t-i}+\varepsilon_{t}$

The bound test approach for the long-run relationship among the variables in equation (2) is based on the Wald test ( $F$ statistic), by imposing restrictions on the long-run estimated coefficients of two period lagged level of variability of export earnings (VEE), opportunity cost of holding reserves (OC), degree of openness of the economy (OPEN), oil price (OP), GDP per capita (GPC), political stability index (PSI) and $\mathrm{CO}_{2}$ emission (COE) to be equal to zero, that is, Ho: $\alpha_{1}=\alpha_{2}=\alpha_{3}=\alpha_{4}=\alpha_{5}=$ $\alpha_{6}=\alpha_{7}=\alpha_{8}=0$ for eqn. 2 . Then the calculated F statistic is compared to the tabulated critical value in (Pesaran (2001).

Thus, Pesaran et al. (2001) compute two sets of critical values for a given significance level. One set assumes that all variables are $I(0)$ and the other set assumes they are all $I(1)$. If the computed F-statistic exceeds the upper critical bounds value, then 
the $\mathrm{H}_{0}$ is rejected. If the F-statistic is below the lower critical bounds value, it implies no cointegration. Lastly, if the F-statistic falls into the bounds then the test becomes inconclusive. Consequently, the order of integration for the underlying explanatory variables must be known before any conclusion can be drawn.

However, the critical values of Pesaran et al (2001) are generated on sample sizes of 500 and 1000 observations and 20000 and 40000 replications, respectively. Narayan (2005a) and Narayan (2005b) argue that such critical values cannot be used for small sample sizes like the one in this study. Given the relatively small sample size in the present study (37 observations), we extract the appropriate critical values from Narayan (2005) which were generated for small sample sizes of between 30 and 80 observations. Data used are obtained from the World Development Indicators (WDI). International reserve (R) is the sum of gold holdings, foreign exchange, IMF position, and Special Drawing Rights. Exports are the value of exports. International crude oil price is obtained from energy monitor. Interest rate on foreign exchange is the discount rate, and openness is measured as the ratio of the value of imports to gross domestic product. The empirical carried out with Eviews 7 software.

\section{Empirical Analysis and Results}

The result of the bound test for equation (4) is presented in Table 1. From the table, the computed F-Statistic is 4.4321 . This value exceeds the upper bounds critical value of 3.32 at the 5\% significance level and 4.26 for the upper bounds critical value for $1 \%$ significance level. This implies that international reserves, variability of export earnings (VEE), opportunity cost of holding reserves (OC), degree of openness of the economy (OPEN), oil price (OP), GDP per capita (GPC), political stability index (PSI) and $\mathrm{CO}_{2}$ emission (COE) are co-integrated. Based on this, we inferred that long run relationship exist among the above mentioned variables.

Table 1: Bounds Test for Long Run Analysis

\begin{tabular}{|c|c|}
\hline & SIC Lags $=2$ \\
\hline Computed F-Statistic: & 4.4321 \\
1\% critical bound value & \\
Lower: & 2.96 \\
Upper: & 4.26 \\
5\% critical bound value & 2.32 \\
Lower: & 3.32 \\
Upper: & \\
\hline
\end{tabular}

Notes: Asymptotic critical value bounds are obtained from Table C1.iii: Case III with unrestricted intercept and no trend for $\mathrm{k}=7$ (Pesaran et al. 2001, p300). 
Table 2: The Estimated Long-run (ARDL) International Reserves Model

\begin{tabular}{|c|c|c|c|c|}
\hline Variable & Coefficient & Std. Error & t-Statistic & Prob. \\
\hline C & 0.208841 & 5.274594 & 0.039594 & 0.9687 \\
\hline LNR $_{t-1}$ & 0.731065 & 0.198099 & 3.690396 & $0.0009 *$ \\
\hline LNVEE $_{t-1}$ & 0.227595 & 0.118035 & 1.928203 & $0.0630^{* *}$ \\
\hline LNOPEN $_{t-1}$ & 0.313856 & 0.425645 & 0.737366 & 0.4664 \\
\hline OC $_{t-1}$ & -0.002310 & 0.008461 & -0.273065 & 0.7866 \\
\hline LNOP $_{t-1}$ & -0.441038 & 0.258051 & -1.709114 & $0.0974 * *$ \\
\hline LNGPC $_{t-1}$ & 0.127653 & 0.266268 & 1.873777 & $0.0861^{* *}$ \\
\hline LNCOE $_{t-1}$ & 0.076202 & 0.251443 & 1.868797 & $0.0671^{* *}$ \\
\hline PSI $_{t-1}$ & -0.706730 & 0.511717 & -1.381095 & 0.1771 \\
\hline
\end{tabular}

Notes: $(*)$ and $(* *)$ indicates $1 \%$ and $10 \%$ significance levels respectively. R-squared: 0.84 , Adjusted R-squared: 0.80, Durbin Watson Statistics: 1.83 and Prob (F-Statistic): 0.0001

Having established cointegration relationship, we estimate Equation (3) in order to obtain the short-run dynamic parameters. Thus, error correction model is used to capture the speed of adjustment of international reserve and explanatory variables considered. This model is expressed below:

$\Delta \ln r=\beta_{0}+\sum_{i=1}^{j} \beta_{1 i} \Delta \ln r_{t-i}+\sum_{i=1}^{j} \beta_{2 i} \Delta \ln v e e_{t-i}+\sum_{i=1}^{j} \beta_{3 i} \Delta o c_{t-i}+\sum_{i=1}^{j} \beta_{4 i} \Delta \ln$ open $_{t-i}$ $+\sum_{i=1}^{j} \beta_{5 i} \Delta \ln o p_{t-i}+\sum_{i=1}^{j} \beta_{6 i} \Delta \ln g p c_{t-i}+\sum_{i=1}^{j} \beta_{7 i} \Delta \ln c o e_{t-i}+\sum_{i=1}^{j} \beta_{8 i} \Delta p s i_{t-i}+\beta_{9} e c t_{t-1}+v_{t}$

The results of the short-run dynamic coefficients in equation (3) are presented in Table 3. The result reveal that estimated coeffient of the lagged value of the residual $\left(E C M_{t-1}\right)$ is negative (-0.59) and statistically significant (0.0001). This means that approximately $59 \%$ of the discrepancy from long run equilibrium in the previous year is adjusted for by the current year. The result also implies that a change in one period lagged value of international reserves $\left(\Delta R_{t-1}\right)$, changes in current value of degree of openness $\left(\Delta \mathrm{LNOPEN}_{\mathrm{t}}\right)$, opportunity cost of holding reserves $\left(\Delta \mathrm{OC} \mathrm{C}_{\mathrm{t}}\right)$, oil price $\left(\Delta \mathrm{LNOP}_{\mathrm{t}}\right)$ and GDP per capita $\left(\Delta \mathrm{LNGPC}_{\mathrm{t}}\right)$ have a positive and statistically significant effect on changes in international reserves $\left(\Delta R_{t}\right)$. This invariably means that the previous year's value of international reserves and the current value of export receipts have a positive influence on the changes noticed in international reserves in the current year. The coefficent of export variability $\left(\Delta \varepsilon_{t}^{2}\right)$ is positive but it is statistically insignificant. 
Table 3: Short Run Error Correction Model

\begin{tabular}{|c|c|c|c|c|}
\hline Variable & Coefficient & Std. Error & t-Statistic & Prob. \\
\hline $\mathrm{C}$ & -0.062905 & 0.067485 & -0.932132 & 0.3585 \\
\hline$\Delta$ LNR $_{\mathrm{t}-1}$ & 0.280033 & 0.141678 & 1.976546 & $0.0570^{* * *}$ \\
\hline$\Delta$ LNVEE $_{\mathrm{t}}$ & -0.084460 & 0.058108 & -1.453507 & 0.1561 \\
\hline$\Delta$ LNOPEN $_{\mathrm{t}}$ & 0.985403 & 0.450374 & 2.187965 & $0.0363 * *$ \\
\hline$\Delta \mathrm{OC}_{\mathrm{t}}$ & 0.010321 & 0.004570 & 2.258407 & $0.0311^{* *}$ \\
\hline$\Delta$ LNOP $_{\mathrm{t}}$ & 0.952856 & 0.310040 & 3.073337 & $0.0044^{*}$ \\
\hline$\Delta$ LNGPC $_{t}$ & 0.725678 & 0.057358 & 3.031997 & $0.0025^{*}$ \\
\hline ecm $_{\mathrm{t}-1}$ & -0.586061 & 0.198716 & -2.949242 & $0.0060^{*}$ \\
\hline
\end{tabular}

Notes: $(*),(* *)$ and $(* * *)$ indicates $1 \%, 5 \%$ and $10 \%$ significance levels. R-squared: 0.68, Adjusted R-squared: 0.66 , Durbin Watson Statistics: 1.86 and Prob (F-Statistic): 0.0003.

In addition, Table 3 also reveals the diagnostic tests of our model and reveals the absence of serial correlation, specification errors and non-normality. These results indicate that our estimated international reserve model is well specified. Thereafter, it is necessary to check for the stability of the international reserves demand function. This is because of the importance of the stability of the international reserves function for an effective foreign reserve holding policy. Therefore it necessary to test whether the estimated international reserves ARDL equation has shifted over time. This is presented in figure 1 and 2. As can be observed from Figures 3 and 4, the CUSUM and CUSUM Square parameter stability tests indicate that the parameters are stable during the sample period (1970-2010).

Figure 3

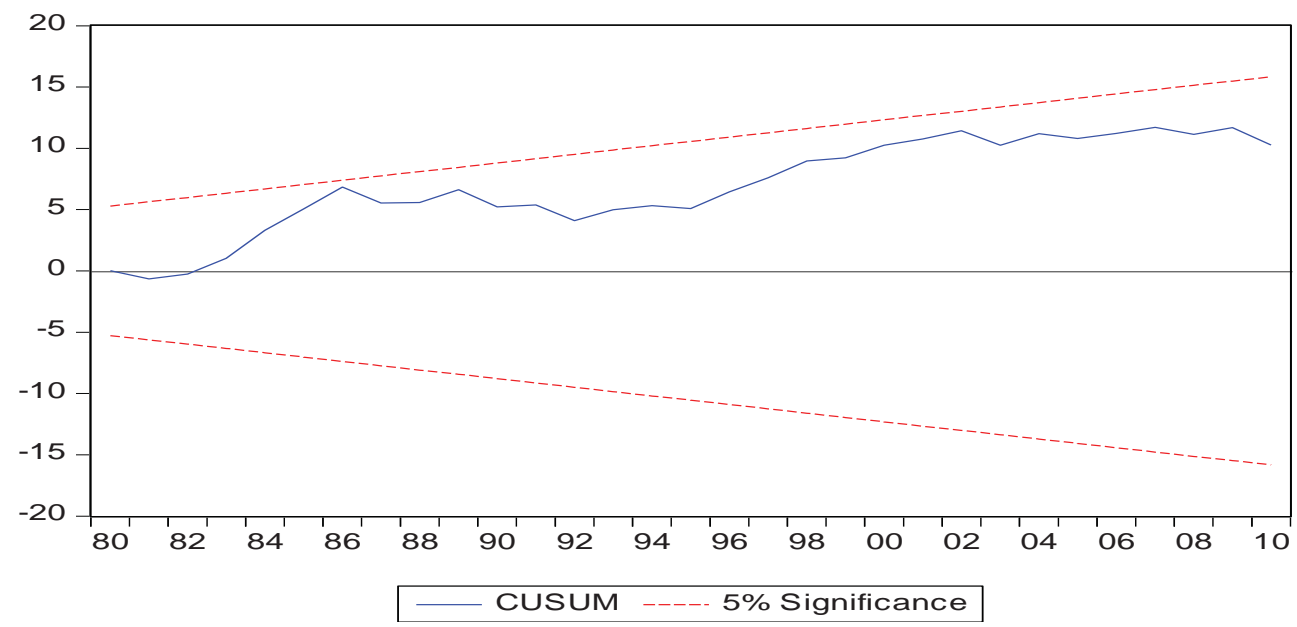


Figure 4

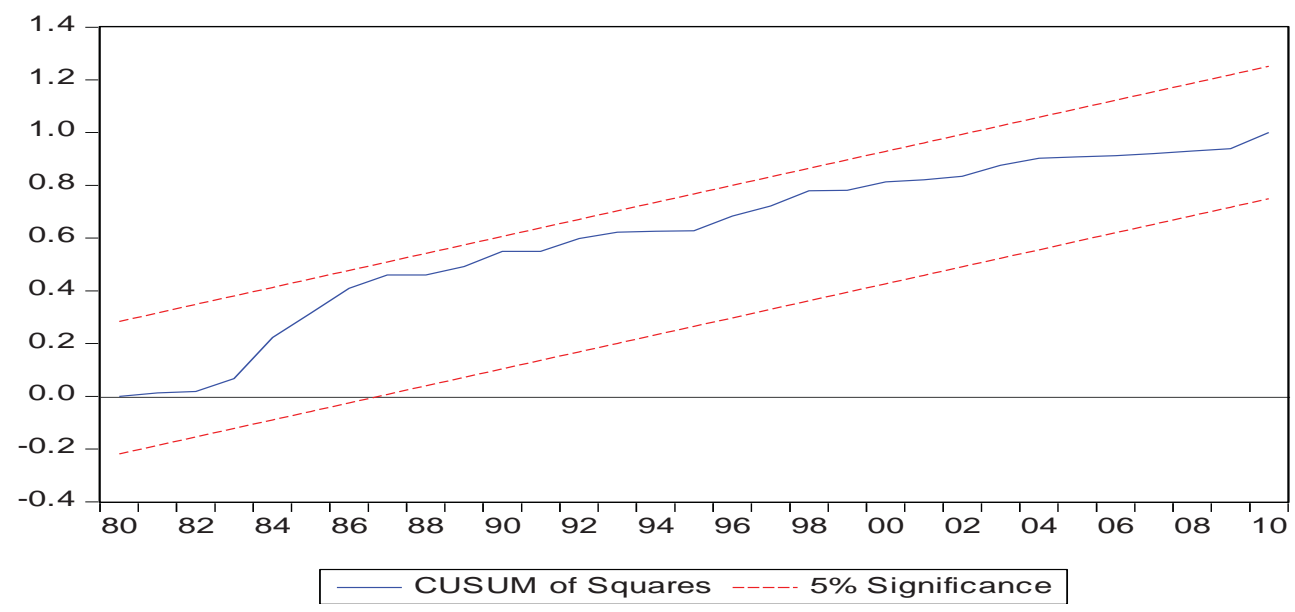

\section{Conclusion}

This paper examined the long-run and short-run determinants of international reserves in Nigeria as regards to sustainable management of reserve holdings. It includes three key dimensions (economic, social and political) of sustainable development as independent variables in the estimated model. Based on theoretical linkages, variables like variability of export earnings (VEE), opportunity cost of holding reserves (OC), degree of openness of the economy (OPEN), oil price (OP), GDP per capita (GPC), political stability index (PSI) and $\mathrm{CO}_{2}$ emission (COE) were considered between 1970 and 2010. The study makes use of error correction mechanism and bounds testing approach to cointegration within an ARDL framework.

The result reveals that in the long-run; one period lagged value of international reserves, variability of export earnings, GDP per capita and $\mathrm{CO}_{2}$ emission were positive and statistically significant while oil price was negatively related to international reserves. In the short-run, the one-period lagged value of international reserves, degree of openness of the economy, opportunity cost of holding reserves, oil price and GDP per capita were positively related to international reserves and statistically significant.

The implication of these results is that government should effectively control the level of environmental degradation occasioned by crude oil exploration in order to reduce the level of $\mathrm{CO}_{2}$ emission to avoid the negative impact of climate change. It also follows that to increase external reserve holding, it is essential to pursue and implement macroeconomic policies that can considerably relax the binding constraint on the availability of foreign exchange. Also, the short-run estimates also revealed 
that the estimate of the opportunity cost variable via the interest rate mechanism is sensitive to reserves. However, there is need to investigate further the determinant for reserves using an export driven model such as Iyoha's (1973), given the desire to promote export-led growth in a sustainable manner. This could be pursued using relatively more sophisticated econometric techniques.

Evidently, policies based on short-term use of resources, particularly crude oil extraction is obviously unsustainable. Therefore, the need for a comprehensive action plan that takes into account the negative consequence of crude oil production such as oil spillage and gas flaring should be put in place in a bid to enhance a sustainable external reserves accumulation and management.

\section{REFERENCES}

Abeng, M. O. (2007). Foreign exchange reserve accumulation. CBN Bullion 31.3: 3250.

Abdullateef, U. and Waheed, I. (2010). External reserve holdings in Nigeria: implications for investment, inflation and exchange rate. Journal of Economics and International Finance Vol.2 No. 9 pp183-189.

Aizenman, J. (2005). Financial liberalization in Latin America in the 1990s: a reassessment. The World Economy 28.7: 959-983(25).

Aizenman, J. and Lee, J. (2005). International reserves: precautionary vs. mercantilist views, theory and evidence. IMF Working Paper 198.

Aizenman, J. and Marion, N. (2003). The high demand for international reserves in the far east: what's going on? Journal of the Japanese and International Economies 17: 370-400.

Aizenman, J., Lee, Y. and Rhee, Y. (2004). International reserves management and capital mobility in a volatile world: policy considerations and a case study of Korea. e-Scholarship Repository Paper No. 569. http://repositories.cdlib.org/ucscecon/569.

Badinger, H. (2004). Austria's demand for international reserves and monetary disequilibrium: the case of a small open economy with a fixed exchange rate regime. Economica 71.1: 39-55.

Ball, C. P. and Reyes, J. (2006). International reserve holdings: interest rates matter! Forthcoming Applied Economic Letters.

Bankole, A. S, Olaniyan, O., Oyeranti, A., and Shuaibu, M. I. (2011). Demand for international reserves in Nigeria: A case for reserve accumulation in Nigeria. Central Bank Economic and Financial Review Vol. 49 No. 3

Ben-Bassat, A. and Gottlieb, D. (1992). On the effect of opportunity cost on international reserve holdings. The Review of Economics and Statistics 74.2: 329-332.

Bockermann, A., Meyer, B., Omann, I., Spangenberg, J.H. (2005) 'Modelling sustainability. Comparing an econometric (PANTA RHEI) and a systems dynamics model (SuE)', Journal of Policy Modelling, Vol. 27, pp.189-210.

Cheung, Y. and Ito, H. (2007). A cross country analysis of international reserves. Paper presented at the 2006 APEA Conference (April). http://web.pdx.edu/ ito/Reserves-II_27April07.pdf.

Courchene, T. J. and Youssef, G. M. (1967). The demand for international reserves. The Journal of Political Economy 75.4: 404-413 Part 1(Aug).

Dooley, M. P., Folkerts-Landau, D. and Garber, P. (2005). The revived Bretton woods system: the effects of periphery intervention and reserve management on interest rates and exchange rates in center countries. NBER Working Paper 10332. 
Dow, J. P. (2001). The demand for excess reserves. Southern Economic Journal 67.3: 685-700.

Edward, S. (1984). Demand for international reserves and monetary equilibrium. Review of Economics and Statistics 66: 495-500.

Edwards, S. (1983). The demand for international reserves and exchange rate adjustments: the case of LDCs, 1964-1972. Economica, 50: 269-280.

Elbadawi, I. A. (1990). The Sudan demand for international reserves: a case of a labor exporting country. Economica 57.225: 73-89.

Pesaran, M.H., Y. Shin, and R.J. Smith, (2001). Bounds testing approaches to the analysis of level relationships. Journal of Applied Econometrics 16 (3), 289-326.

Elhiriaka, A. and Ndikumana, L. (2007). Reserves accumulation in African countries: sources, motivations, and effects. Proceedings of the African Economic Conference on Opportunities and Challenges for Africa in the Global Arena, organized by AFDB and ECA, 15-17th November 2007, Addis Ababa, Ethiopia.

Engle, R. F. and Granger, C. W. J. (1987). Co-Integration and error correction: Representation, estimation, and testing. Econometrica. 55.2: 251-276.

Flood, R. and Marion, N. (2002). Holding international reserves in an era of high capital mobility. IMF Working Paper No. 62.

Ford, J. L. and Huang, G. (1994). The demand for international reserves in china: an error correction model with domestic monetary disequilibrium. Economica New Series 61.243: 379-397.

Frenkel, J. (1983). International liquidity and monetary control, international money and credit: The policy roles, ed. by George M. von Furstenberg, (Washington; International Monetary Fund), pp. 65-109.

Frenkel, J. A. and Jovanovic, B. (1981). Optimal international reserves: a stochastic framework. The Economic Journal 91.362: 507-514.

Harrod, R. F. (1953). The imbalance of international payments," International Monetary Fund (IMF) Working Paper 3: 1-46.

Heller, H. R. (1966). Optimal international reserves. The Economic Journal 76.302: 296-311.

Heller, R. H. and Khan, M. S. (1978). The demand for international reserves under fixed and floating exchange rates. International Monetary Fund (IMF) Working Paper 25.4: 623-49.

IMF. (2003). Guidelines for foreign exchange reserve management. Prepared by the Monetary and Exchange Affairs Division, International Monetary Fund (IMF) March.

Iyoha, M. (1976). Demand for international reserves in less developed countries: a distributed lag specification. The Review of Economics and Statistics 58.3: 351-55.

Iyoha, M. A. (1973). The optimal balance-of-payments strategy of a less developed country. Economic Record 49. pp 270-279.

Jarque, C. M. and Bera, A. K. (1981). Efficient tests for normality, homoscedasticity and serial independence of regression residuals: Monte Carlo evidence. Economics Letters 7 (4): 313-318.

Jo, G. (2007). The determinants of international reserve hoarding in Korea: cointegration and error correction approach. Presented at Singapore Economic Review Conference (SERC) (Aug.). Retrieved Nov. 11, 2008 from https://editorialexpress.com/cgi-bin/conference/download. cgi?db_name=SERC2007\&paper_id=205.

Johansen, S. (1988). Statistical analysis of cointegrating vectors. Journal of Economic Dynamics and Control, 12, 231-54.

Johansen, S., and Juselius. K. (1990). Maximum likelihood estimation and inference on Cointegration: with applications to the demand for money. Oxford Bulletin of Economics and Statistics,52, pp169-210.

Kelly, M. G. (1970). The demand for international reserves. American Economic Review 60: 655-667.

Kenen, B. P. and B. Yudin, E. 1965. The demand for international reserves. Review of Economics and Statistics 47: 242-250. 
Khan, K. and Ahmed, E. (2005). The demand for international reserves: a case study of pakistan. The Pakistan Development Review 44.4:939-957 (Part II).

Lane, R. P. and Burke, D. (2001). The empirics of foreign reserves. Forthcoming, Open Economies Review (February) Economics Department, Trinity College Dublin, Dublin 2, Ireland.RetrievedNov.10,2008, from http://www.tcd.ie/Economics/TEP/2001_papers/TEPNo5PL21.pdf.

Lee, J. (2004). Insurance value of international reserves: an option pricing approach. IMF Working Paper 175.

Lizondo, J. and Mathieson, D. (1987). The stability of the demand for international reserves. Journal of International Money and Finance 6.3: 251-282.

Miller, M. and Orr, D. (1966). A model of the demand for money by firms. Quarterly Journal of Economics 80: $413-35$.

Narayan, K. P. (2005a). The saving and investment nexus for China: Evidence from Cointegration tests." Applied Economics, 37: 1979-90.

Narayan, S. (2005b). Estimating income and price elasticities of imports for Fiji in a cointegration framework. Economic Modeling, Elsevier, vol. 22(3), pages 423-438.

Nda, M. (2006). Effective reserve management in Nigeria: issues, challenges and prospects $C B N B u l$ lion 30.3: 45-51.

Nerlove, M. (1972). Lags in economic behaviour. Econometrica 40: 221-251.

Obstfeld, M., Shambaugh, J. C. and Taylor, A. M. (2008). Financial stability, the trilemma, and international reserves. NBER Working Paper 14217.

Parent, N. and Gosselin, M. (2005). An empirical analysis of foreign exchange reserves in emerging asia. Bank of Canada Working Paper 05/38.

Pearce, D.W. and Atkinson, G. (1993). Capital theory and the measurement of sustainable development: an indicator of weak sustainability, Ecological Economics, Vol. 8, No. 1, pp.103-108.

Pesaran, H., Shin, Y., and Smith, R. J. (2001). Bounds testing approaches to the analysis of level relationships Journal of Applied Econometrics, 16, 289-326.

Ramsey, J.B. (1969). Tests for specification errors in classical linear least squares regression analysis. Journal of the Royal Statistical Society. 31(2), 350-371.

Sehgal, S. and Sharma, C. (2008). A study of adequacy, cost and determinants of international reserves in India. International Research Journal of Finance and Economics Issue 20. Retrieved Mar. 20, 2008, from http://www.eurojournals.com/finance.htm.

Shuaibu, M. I and Mohammed, I. T. (2013). Demand for international reserve in Nigeria: Evidence from an ARDL specification. Empirical Economic Letters 20 (6)

Spangenberg, J. H., Omann, I. and Hinterberger, F. (2002). Sustainable growth criteria. Minimum benchmarks and scenarios for employment and the environment. Ecological Economics, Vol. 42, No. 3, pp. 429-443.

Spangenberg, J. H. (2002). The changing contribution of unpaid work to the total standard of living in sustainable development scenarios. Int. J. Sustainable Development, Vol. 5, No. 4, p.461-475.

Spangenberg, J. H. (2005). Economic sustainability of the economy: Concepts and indicators. International Journal of Sustainable Development, Vo. 8 No.s 1/2.

Usman, S. (2005). Towards a more strategic management of Nigeria's foreign reserves. Proccedings of the Annual Conference of Nigerian Economic Society (NES) Lagos, 23rd August 2005.

White, H. (1980). A heteroskedasticity-consistent covariance matrix estimator and a direct test for heteroskedasticity. Econometrica 48 (4): 817-838. 